\title{
The Effect of Job Satisfaction and Organizational Commitment Towards Organizational Citizenship Behavior (OCB): A Case Study on Employee of Local Water Company "Tirta Mahakam" Kutai Kartanegara Indonesia
}

\author{
Iskandar $^{*}$ \\ Fakultas Ekonomi dan Bisnis, Universitas Kutai Kartanegara, Indonesia \\ Dedi Januar Hutagalung \\ Fakultas Ekonomi dan Bisnis, Universitas Kutai Kartanegara, Indonesia \\ Raudatul Adawiyah \\ Fakultas Ekonomi dan Bisnis, Universitas Kutai Kartanegara, Indonesia
}

\begin{abstract}
The purpose of this study was to examine the influence of job satisfaction and organizational commitment towards organizational citizenship behavior. The study was a case study on employees of local water company "Tirta Mahakam" located in Kutai Kartanegara Regency. Quality of service will always be a significant factor for organizations that focus on customer satisfaction. It is done to improve business activity and organizational performance. To have excellent quality services depends on the human resources of the organization. The organization needs human resources that are performing well. Human resources/employees who show strong OCB are believed to be able to perform better. That is why organizations need to create employees with strong OCB. This study was a causal associative study using a quantitative approach. Data were collected using a closed questionnaire with a total sample of 83 respondents, and the selection of respondents chosen using simple random sampling. The results showed that job satisfaction and organizational commitment simultaneously affected organizational citizenship. Job satisfaction partially influenced organizational citizenship behavior. Organizational commitment partly influenced organizational citizenship behavior. Job satisfaction was proven to have the most significant influence.
\end{abstract}

JEL : M12

Keywords: organizational citizenship behavior

\section{INTRODUCTION}

Human resources are a very valuable asset and the most important element in achieving organizational goals for both public and private organizations. The focus a leader must have in improving organizational effectiveness is increasing human resources because the effectiveness and success of an organization depend on the quality and performance of human resources within the organization. This is because human resources are the only resources that have the intellect,

\footnotetext{
*Email : iskandar_76@rocketmail.com

Received : 31-09-2019, Accepted: 18-10-2019, Published: 19-12-2019

P-ISSN : 2087-9954, E-ISSN : 2550-0066. DOI : http://dx.doi.org/10.26418/jebik.v8i3.35001
} 
feelings, desires, abilities, and knowledge needed at work. Quality human resources help an organization to develop and sustain its existence.

Human resources and organizational success are intertwined. Organizational success is largely determined by human empowerment itself - this makes human resource management not as an option but as a necessity for an organization to develop. Human empowerment requires an understanding of employee behavior as it becomes one of the requirements for the sustainability of an organization. Employee behavior takes two forms: (1) behavior as expected by job description (intra-role) and (2) additional behavior outside of job description (extra-role). Additional behavior outside of job description in organizations is often referred to as Organizational Citizenship Behavior (OCB).

It has always been interesting to discuss OCB since it is directly related to the behavior of individuals or groups within an organization. OCB is very important in improving services and achieving organizational goals. Regardless of the importance of $\mathrm{OCB}$, many companies have not implemented OCB well. Conceptually, OCB is a behavioral choice that is not part of the formal job requirement, but it supports the effective functioning of the organization (Robbins, Stephen, Judge, \& Timothy, 2013). OCB is an extra-role behavior or voluntary behavior outside of a job description that is not directly or explicitly recognized in the formal reward system and aggressively it can improve the function of organizational effectiveness. OCB is important in a way that it increases productivity, makes efficient use of resources, increases human resources, and increases performance in organizations.

Existing literature explains the two main factors affecting OCB. The first is internal factors originating from within employees themselves, including job satisfaction and organizational commitment. The second is external factors originating from outside of employees, including leadership styles and trust to leaders. Understanding these two factors is the key for any organizations, including companies, to improve OCB on their members or employees.

This present study focused on internal factors, (1) job satisfaction and (2) organizational commitment, as variables to be analyzed. Both can influence OCB on employees and we assumed that these two variables were needed by companies in increasing OCB on employees. Key work attitudes in organizational studies, job satisfaction and organization commitment is job satisfaction and positive feelings about the work to be made as the results of evaluations of various properties (Robbins et al., 2013).

OCB is closely related to organizational commitment. Organizational commitment is one of the driving factors for OCB. According to Mathis \& Jackson (2010), organizational commitment is the degree to which employees believe in accepting organizational goals and will remain or will not leave the organization. Organizational commitment is a form of employee's personal characteristics, usually shown by an attitude of being attentive to work, being responsible, and being loyal to the company. Building a good character of employees takes a strong commitment from the company and even a stronger commitment is needed in maintaining such good character once it has been built to optimize the function of the company itself. 
Perusahaan Daerah Air Minum (PDAM) ${ }^{\dagger}$ Tirta Mahakam is located in Kutai Kartanegara Regency. The company has been engaged in the supply and distribution of clean water in the region since 1981. As the company serves such a vast area and a large number of customers, the company expects its employees to do extra-roles or OCB to help the company achieve its goals easily.

Our observations on employees of PDAM Tirta Mahakam helped us to reveal that the employees had a low level of OCB. They were not happy with the work they did and considered it as simply a boring routine. They also stated that their salary was not enough to support their needs. We also found out that teamwork was not good among employees. Nevertheless, the company seemed to ignore the complaints of its employees.

The low organizational commitment affected the way employees did their work-they finished their responsibility, yet it took so much time to complete. The low level of involvement and sense of attachment to the organization could be seen from employees often leaving for personal needs during working hours. Most employees also liked to extend their lunchtime- the normal lunchtime was one hour, yet they would leave for lunch for two to three hours, and some even came back to the office when it was about time to go home.

Based on the description above, this study seeks to analyze and examine: (1) Do job satisfaction has influence the OCB of employees? (2) Do organizational commitment, has influence the OCB of employees? This study basically aims to analyze and examine the influence of job satisfaction and organizational commitment variables on Organizational Citizenship Behavior (OCB) employees.

\section{LITERATURE REVIEW}

\subsection{Human Resource Management}

Basically there are three sources in an organization namely human resources, financial resources and physical resources, and according to researchers Human resources are very important and directly affect the productivity of an organization. And human resources are the most important factor affecting organizational performance. Companies can have a leading position with the use of effective human resources in increasing productivity and organizational performance in market competition conditions (Yilmaz \& Bulut, 2015).

Human Resource Management (HRM) is an acknowledgment on the importance of an organization's workforce as a human resource to realize organizational goals; it also represents the use of several functions and activities to ensure that human resources are used effectively and fairly used for the interests of individuals, organizations, and the community. HRM systems cannot be fully understood without considering their interrelationships with other elements of an organization to which it is inextricably bound. Likewise, interdependencies bind HRM systems to the external environment in which they are embedded. Thus, strategic HRM is inherently contextualized and dynamic (Jackson, Schuler, \& Jiang, 2014). Human resource management refers to the policies and practices one needs to carry out the people or human resource aspects of

\footnotetext{
${ }^{\dagger}$ A local water company owned by the local government
} 
management position including recruiting, screening, training, rewarding and appraising (Dessler, 2013).

Successful organizations need employees who perform more than usual work tasks (extra-roles) that will deliver performance beyond expectations. In today's dynamic workplace, where tasks are increasingly carried out by employees and flexibility is very important, employees who engage in "good citizenship" behavior will help other employees, volunteer for extra work, avoid unnecessary conflicts, respect rules and conditions apply and patiently tolerate coercion and interference related to work (Robbins et al., 2013). Employee job satisfaction is assumed to be the main determinant of OCB. Satisfied employees will talk positively about the organization, help others, and employees become more proud of task assignments because employees want to reciprocate organizational experiences (Robbins et al., 2013).

\subsection{Organizational Citizenship Behavior (OCB)}

OCB refers to individual behavior that is discretionary, not directly or explicitly recognized by the formal reward system, and that in aggregate promotes the effective functioning of the organization (Podsakoff, Podsakoff, MacKenzie, Maynes, \& Spoelma, 2014). Robbins et al. (2013) define OCB as a behavioral choice that is not part of the formal job requirement, but it supports the effective functioning of the organization.

In general, OCB is a person's voluntary commitment within an organization or company that is not part of his or her contractual tasks so it is not included in the formal reward system. In other words, OCB is a positive individual behavior outside of the formal work (in-role) that contributes positively to the psychological and social environment at work. Organ \& Lingl (1995) identified five major types (dimensions) of OCB as follows:

1.Altruism can be called simply helping or helpfulness. Altruism consists of voluntary actions that help others with an organizationally relevant task such as showing employees how to accomplish difficult tasks.

2.Conscientiousness is a discretionary behavior that goes well beyond the minimum role requirement level of the organization, such as coming to work earlier and using the working hours well.

3.Sportsmanship is demonstrations of willingness to tolerate minor and temporary personnel inconveniences and impositions of work without grievances, complaints, appeals, accusations, or protest.

4.Courtesy is demonstrated in the interest of preventing creations of (interpersonal) problems for co-workers.

5. Civic virtue is a behavior on the part of an individual that indicates that employee responsibly participate in, is involved in, or concerned about the life of the company

\subsection{Job Satisfaction and $O C B$}

Studies conducted by Koning \& Kleef (2015), Chahal \& Mehta (2010) conclude that there is a positive and significant effect of job satisfaction on OCB. Several other studies conducted by Pavalache-ilie (2013), and Intaraprasong, Dityen, \& Krugkrunjit (2012) show the results that employees who are satisfied with their work tend to display higher organizational citizenship behavior. Job satisfaction refers to positive attitude employees show towards their work by being disciplined and showing good performance. According to Rajeswari \& 
Adhimoolam (2015), job satisfaction or dissatisfaction is an emotional response to a value judgment.

Robbins et al. (2013) define job satisfaction as the positive feeling about one's job resulting from an evaluation of its characteristics. The higher a person's job satisfaction, the more positive he/she will be about the job-and the vice versa. Thus, in conclusion, job satisfaction is a pleasant emotional feeling for employees that will make a positive contribution to their work environment.

Ramawickrama, Opatha, \& Kumari (2017) defined the construct of job satisfaction as consisting of five facets of pay, promotion, coworkers, supervision, and the work itself. The explanation is as follows:

1.Satisfaction with the work itself. Jobs provide opportunities for employees to learn according to their interests and opportunities to be responsible in doing their work. The two-factor theory explains that work can be a factor that drives a strong level of motivation that it helps to produce good work performance.

2.Pay. Job satisfaction will be formed if the amount of money received by employees matches the workload and is balanced with other employees.

3.Promotion. Promotion is a form of appreciation received by employees in the organization. Employee job satisfaction will be high if they are promoted based on work performance.

4. Satisfaction with supervision. Supervision by superiors takes the form of paying attention to the work done by employees, advising and assisting employees, and building good communication. Employee job satisfaction will be high if supervision is done to motivate employees.

5. Satisfaction with colleagues. A harmonious relationship, friendship, and mutual assistance between employees in the organization will create a conducive situation at work thus increasing the satisfaction of employees.

\subsection{Organizational Commitment and Organizational Citizenship Behavior}

A study conducted by Zayas-ortiz, Rosario, Marquez, \& Gruñeiro (2015) found that organizational commitment influences organizationalnal citizenship behavior. Organizational commitment plays an important role in the quality of an employee's performance in the company. Organizational commitment is the level of employee trust to accept the company's values and goals so that they have the desire to remain part of the company. Employees who have emotional closeness with their organizations tend to be able to trust the values of the company, this employee will support the sustainability of the company by giving ideas and contributing more to the company (Conscientiousness). The similarity of employee values and company values will result in an atmosphere of mutual support between employees, this will create a harmonious relationship between colleagues (Courtessy) and a sense of empathy / want to help towards colleagues who are experiencing difficulties related to work (Altruism).

Organizational commitment is a condition to the extent to which an employee sided with a particular organization and its purpose and intends to maintain membership in the organization (Telaumbanua, Sinulingga, \& Iskandarini, 2019). Organizational commitment according to AlJabari \& Ghazzawi (2019) is an individual's self-drive to do something to support the success of the organization in accordance with its objectives and to put the interests of the organization as 
his/her priority. Thus, it can be concluded that organizational commitment is a psychological condition or character of an employee to trust the organization and to remain in the organization by showing his/her maximum performance. In organizational commitment, employees identify themselves with a particular organization and its goals and they expect to remain a member of the organization (Mercurio, 2015). Organizational commitment has three components, namely:

1. Affective commitment is defined as the employee's positive emotional attachment to the organization. An employee who is affectively committed strongly identifies with the goals of the organization and desires to remain a part of the organization.

2. Continuance commitment is the gains versus losses of working in an organization. A good example of continuance commitment is when employees feel the need to stay with their organization because their salary and fringe benefits will not improve if they move to another organization.

3. Normative commitment refers to feelings of obligation to remain with the organization because of ethic or moral reason. Normatively committed employees feel that leaving their organization would have disastrous consequences and feel a sense of guilt about the possibility of leaving.

\subsection{Hypothesis}

Based on the literature review and research framework, we proposed the following hypothesis:

H1. Job satisfaction partially affects the OCB of employees.

H2. Organizational commitment partially affects the OCB of employees

\section{RESEARCH METHOD}

\subsection{Study Site}

The study took place in Kutai Kartanegara, a regency in East Kalimantan Province. The subject of the study was employees of PDAM Tirta Mahakam, a local water company owned by the local government of Kutai Kartanegara.

\subsection{Population and Sample}

There were 396 employees in the company, consisting of 104 employees working in the headquarters and 292 employees working in the branch offices. The study focused on those working in the headquarters. The Slovin Formula was used to determine the number of samples:

$n=\frac{N}{1+N e^{2}}$

Where

$\mathrm{n} \quad=$ sample size

$\mathrm{N}=$ population

$\mathrm{e} \quad=$ critical value $5 \%$

Thus, the calculation of the sample size looks like this:

$$
\begin{aligned}
n & =\frac{104}{1+104(5 \%)^{2}} \\
& =\frac{104}{1.26}=82.54=83
\end{aligned}
$$


Thus, the study involved 83 respondents. The sample was taken using simple random sampling, where the sample was chosen randomly without regard to strata in the population.

\subsection{Data Analysis Model}

This study used multiple regression analysis. This analysis was used to determine the effect of independent variables (job satisfaction and organizational commitment) on the dependent variable (Organizational Citizenship Behavior). In general, the multiple linear regression equation is $\mathrm{Y}=\mathrm{a}+\mathrm{b} 1 \mathrm{X} 1+\mathrm{b} 2 \mathrm{X} 2+\mathrm{e}$ (Sugiyono, 2015). Where ;

Y : Organizational Citizenship Behavior (OCB)

a : Constants

$\mathrm{X} 1 \quad$ : Job satisfaction

X2 : Organizational commitment

b1, b2 : Regression coefficient or the number of changes in the dependent variable due to changes in each unit of the independent variable

$\mathrm{e}$ : Residual Error

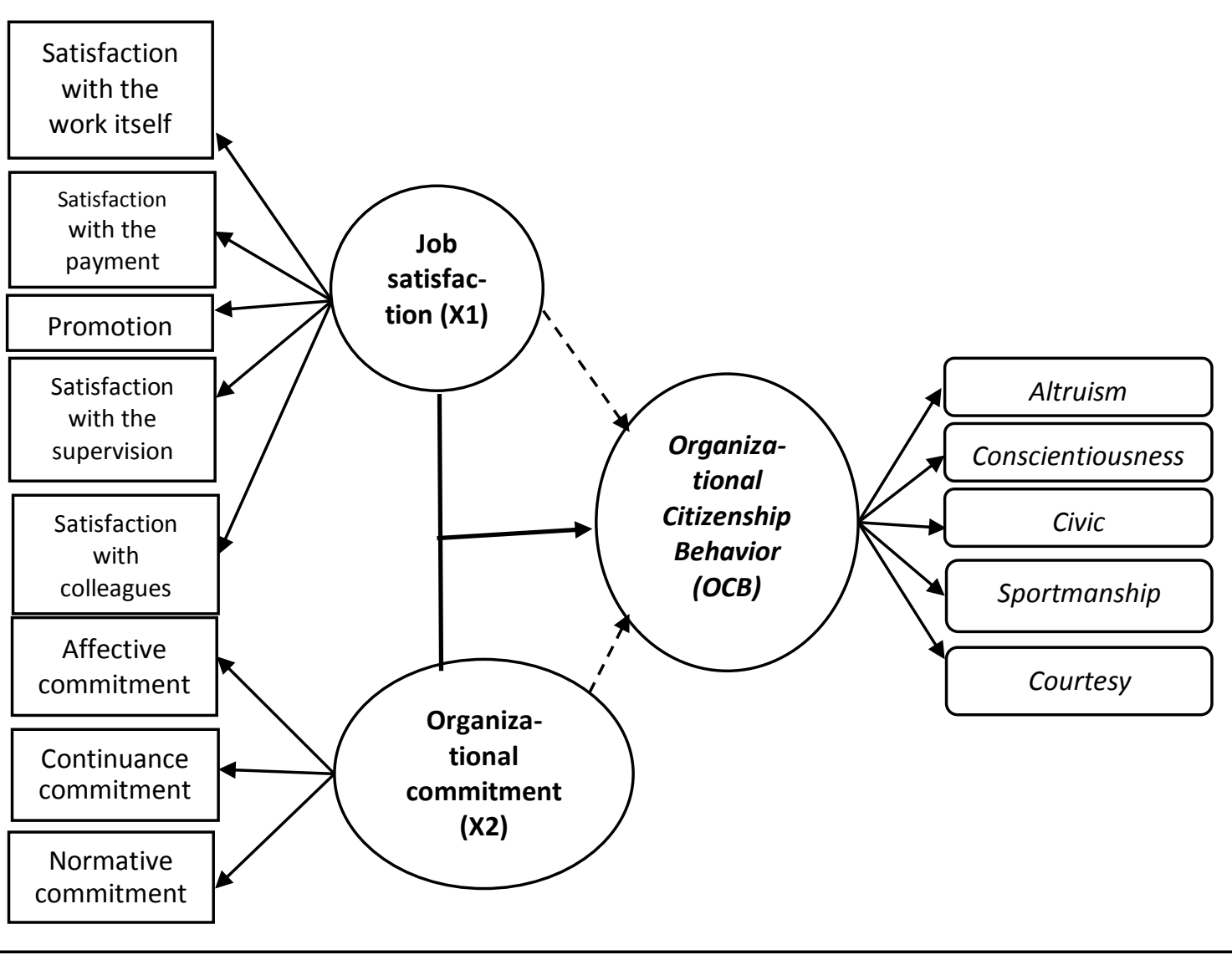

Figure 1. Research Framework 


\section{RESULTS AND DISCUSSION}

\subsection{Results}

Table 1 confirms that the 13 items used to measure the variables in this study (job satisfaction, organizational commitment, and OCB) had an $r_{\text {count }}$ bigger than $r_{\text {table. These results }}$ indicated that all items were valid $\left(r_{\text {count }}>r_{\text {table }}\right)$.

Table 1. Validity and Reliability Test

\begin{tabular}{|c|c|c|c|c|c|c|}
\hline No & Indicator & $\mathbf{r}_{\text {count }}$ & $\mathbf{r}_{\text {table }}$ & $\begin{array}{c}\text { Cronbach } \\
\text { Alpha }\end{array}$ & & Iote \\
\hline 1 & $\mathrm{X}_{1.1}$ & 0.673 & 0.220 & \multirow{5}{*}{0.757} & Valid & \multirow{5}{*}{ Reliable } \\
\hline 2 & $\mathrm{X}_{1.2}$ & 0.540 & 0.220 & & Valid & \\
\hline 3 & $X_{1.3}$ & 0.839 & 0.220 & & Valid & \\
\hline 4 & $\mathrm{X}_{1.4}$ & 0.820 & 0.220 & & Valid & \\
\hline 5 & $\mathrm{X}_{1.5}$ & 0.722 & 0.220 & & Valid & \\
\hline 6 & $\mathrm{X}_{2.1}$ & 0.849 & 0.220 & \multirow{3}{*}{0.692} & Valid & \multirow{3}{*}{ Reliable } \\
\hline 7 & $\mathrm{X}_{2.2}$ & 0.746 & 0.220 & & Valid & \\
\hline 8 & $\mathrm{X}_{2.3}$ & 0.785 & 0.220 & & Valid & \\
\hline 9 & $Y_{1.1}$ & 0.693 & 0.220 & \multirow{5}{*}{0.708} & Valid & \multirow{5}{*}{ Reliable } \\
\hline 10 & $\mathrm{Y}_{1.2}$ & 0.802 & 0.220 & & Valid & \\
\hline 11 & $Y_{1.3}$ & 0.685 & 0.220 & & Valid & \\
\hline 12 & $\mathrm{Y}_{1.4}$ & 0.682 & 0.220 & & Valid & \\
\hline 13 & $Y_{1.5}$ & 0.591 & 0.220 & & Valid & \\
\hline
\end{tabular}

The Cronbach's Alpha value of the three variables was 0.757 (job satisfaction) with five statements, 0.692 (organizational commitment) with three statements, and 0.708 (OCB) with a total of fivestatements. The minimum standard value for reliability is 0.40 . Because the Cronbach's Alpha value of the three variables turned out to be greater than 0.40 , the questionnaires were reliable. The Cronbach's Alpha value was 0.692 to 0.757 , so it was declared reliable. The interpretation of the Cronbach's Alpha reliability level is presented in Table 2.

Table 2. Reliability Level based on the Alpha Value

Normality Test

\begin{tabular}{cc}
\hline Alpha & Reliability Level \\
\hline $0.00-0.20$ & Very Low \\
$>0.20-0.40$ & Low \\
$>0.40-0.60$ & Moderate \\
$>0.60-0.80$ & High \\
$>0.80>1.00$ & Very High \\
\hline
\end{tabular}

Source: Triton (2006:248)

Normality tests aim to assess the data distribution of a variable, whether the data is normally distributed or not. In parametric statistics, normal data distribution is necessary and is an absolute requirement. A good regression model is to have residual values that are normally distributed. The model used is the Kolmogorov-Smirnov (K-S) test with the following criteria:

- If the significance value $>0.05$, then the data is normally distributed. 
- If the significance value is $<0.05$, then the data is not normally distributed.

Table 3 confirmed that the residual significance value of 0.200 was greater than 0.05 . Therefore, in accordance with the basis of decision-making in the Kolmogorov-Smirnov normality test, it can be concluded that the data were normally distributed. Thus, the requirement for the normality test was met.

Table 3. Tests of Normality

\begin{tabular}{lcccccc}
\hline & \multicolumn{3}{c}{ Kolmogorov-Smirnova } & \multicolumn{3}{c}{ Shapiro-Wilk } \\
\cline { 2 - 7 } & Statistic & df & Sig. & Statistic & df & Sig. \\
\hline $\begin{array}{l}\text { Unstandardized } \\
\text { Residual }\end{array}$ & .051 & 83 & $.200 *$ & .989 & 83 & .738 \\
\hline
\end{tabular}

\section{Multicollinearity Test}

The multicollinearity test aims to examine if a linear correlation between the independent variables in the regression model exists. The prerequisites that must be met in the regression model are the absence of multicollinearity. Two independent variables are said to have no multicollinearity under the following conditions:

- If the tolerance value $>0.10$, there is no multicollinearity in the regression model.

- If the tolerance value $<0.10$, there is multicollinearity in the regression model.

The result of the test showed that the tolerance value between the two independent variables of job satisfaction and organizational commitment was 0.712 or $>0.10$, so it can be concluded that there was no multicollinearity in the regression model.

\section{Heteroscedasticity Test}

Heteroscedasticity test is used to determine whether a deviation of the classical assumption exists, which is the variance of the residual inequality for all observations in the regression model. The model used is the glejser test with the following test conditions:

- If the significance value $>0.05$, heteroscedasticity does not occur.

- If the significance value $<0.05$, heteroscedasticity occurs.

Based on the test results, the significance of job satisfaction was 0.321 and organizational commitment was 0.383 or $>0.05$; thus, it can be concluded that heteroscedasticity did not occur in the two variables.

Table 4. Results of Multiple Regression Analysis

\begin{tabular}{lcc}
\hline \multirow{2}{*}{ Model } & \multicolumn{2}{c}{$\begin{array}{c}\text { Unstandardized } \\
\text { Coefficients }\end{array}$} \\
\cline { 2 - 3 } & B & Std. Error \\
\hline $1 \quad$ (constant) & 1.850 & \\
\hline Job satisfaction & .300 & .388 \\
\hline $\begin{array}{c}\text { Organizational } \\
\text { commitment }\end{array}$ & .280 & .325 \\
\hline
\end{tabular}


Based on the results of the analysis, a model of the equation for the multiple linear regression can be written as: $\mathrm{Y}=1.850+0.300 \mathrm{X} 1+0.280 \mathrm{X} 2$. This equation can be interpreted as follows:

1.A constant value of 1.850 means if there are no independent variables, then the OCB of employees is 1.850 .

2.The coefficient value of 0.300 means the addition of job satisfaction by one will increase OCB by 0.300 .

3. The coefficient value of 0.280 means the addition of organizational commitment by one will increase OCB by 0.280 .

\section{F test (Simultaneous)}

The $\mathrm{F}$ test was used to determine the extent of simultaneous influence of job satisfaction and organizational commitment on OCB. The results of the F-test are presented in Table 5.

Table 5. ANOVA ${ }^{\mathrm{a}}$

\begin{tabular}{lrrrcc}
\hline \multicolumn{1}{c}{ Model } & $\begin{array}{r}\text { Sum of } \\
\text { Squares }\end{array}$ & \multicolumn{1}{c}{ df } & Sean & & \\
Square & F & Sig. \\
\hline Regression & 5.332 & 2 & 2.666 & 25.746 & $.000^{\mathrm{b}}$ \\
& & & & & \\
Residual & 8.284 & 80 & .104 & & \\
Total & 13.616 & 82 & & & \\
\hline
\end{tabular}

From the ANOVA test or $\mathrm{t}$-test, the calculated $\mathrm{F}$ was 25.746 while the $\mathrm{F}_{\text {table }}$ value was 3.15; this means that the calculated $\mathrm{F} \geq \mathrm{F}_{\text {table }}$ with a significance level of 0.000 . Because the probability of 0.000 was much smaller than 0.05 , the regression model could be used to predict OCB. It can be concluded that the proposed hypothesis was accepted, meaning that the independent variables of job satisfaction and organizational commitment simultaneously affected OCB.

t-test (partial)

To determine the effect of job satisfaction (X1) and organizational commitment (X2) individually or partially on OCB (Y), t-test was done. The degree of freedom df $=(n-k-1)$ was 80 with a significance level of $5 \%(0.05)$, then $t_{\text {table }}$ was equal to 1.667 . Table 6 presents the results of the t-test or partial test:

Table 6. Partial Test Results (t-test)

\begin{tabular}{llcc}
\hline \multicolumn{1}{c}{ Model } & $\mathrm{t}$ & Sig. \\
\hline 1 & (constant) & 5.477 & 0.000 \\
\cline { 2 - 4 } & Job satisfaction & 3.757 & 0.000 \\
\cline { 2 - 3 } & Organizational commitment & 3.141 & 0.002 \\
\hline
\end{tabular}

\subsection{Discussion}

Job satisfaction significantly influences the behavior of Citizenship (OCB) employees of PDAM Tirta Mahakam. The more positive the job satisfaction feeling of an employee in his work, then the employee will tend to interpret the work and tasks they do with full responsibility and dedication. With a positive feeling of satisfaction, will encourage employees to work 
optimally in completing their work, even able to do things outside their duties so that this encourages the creation of Citizenship Behavior (OCB). Organizational citizenship behavior (OCB) aims to protect the organization against destructive and undesirable behaviors which prevent the organization's healthy operations, improves incumbents' skills and abilities and increases performance and productivity of organization by effective coordination. In this respect OCB is very closely related with organization's competiveness, organizational learning, adaptations for environment and incumbents' loyalty, commitment, performance and altruism (Basim \& Şeşen, 2006).

Organizational commitment significantly influences the behavior of Citizenship (OCB) PDAM Tirta Mahakam employees. Employees who have high organizational commitment are treated as members of the organization's extended family. Employees who have a high sense of involvement in the company will generate positive feelings so that they can be oriented to cooperation so as to produce good work. Pavalache-ilie (2013) states that people who are satisfied with their work tend to often adopt organizational citizenship behaviors. These behaviours are associated with the self-efficacy, the internality, and length in service within the organization. In public organizations, the availability to contributing with extra-role behaviours in the work place is more intensive than in the private ones. People having higher education levels get more involved in volunteer behaviours.

The results of this study indicate the importance of identifying variables (satisfaction and commitment) that have a close relationship with OCB. In addition, this shows how the combination of these two variables can help employees understand OCB. So that management can use this to effectively manage performance and well-being in the organization.

Job satisfaction, organizational commitment, and OCB employees at PDAM Tirta Mahakam were found at a high level. These results are in line with Ariani's study (2014) which proves that personality pride and affective organizational commitment have a positive effect on OCB. In other words, employees are satisfied with their work and feel committed, which is why their OCB is also high. Management gives employees clear expectations and employees tell management what they need to do their jobs better. We found that relations between colleagues are quite smooth.

OCB on employees will appear if employees have a high level of satisfaction with their work. In addition to job satisfaction, another factor that can bring up Organizational Citizenship Behavior behavior in employees is organizational commitment. Organizational commitment is a form of employee loyalty to the company where if employees have high loyalty to the company, employees will be willing to use all their capabilities for the benefit of the company in their place. In general, there are similar frequencies of Organizational Citizenship Behaviors in the public and private sectors. In public institutions, however, OCBs in the interpersonal dimension are more frequent, while in private institutions they occur more commonly in the organizational dimension. Most positively correlated with OCBs is the affective dimension of organizational commitment (Grego-planer, 2019).

This organizational condition is in line with the results of the study of Khan \& Rashid (2015) which basically emphasizes the aspect of employee organizational commitment and was found to be significantly correlated with OCB. Likewise, the results of the study of Shafazawana, Ying, Zuliawati, \& Sukumaran (2015) found that, job satisfaction, organizational commitment 
and organizational citizenship behavior showed a statistically significant and positive relationship.

\section{CONCLUSION}

Thus it can be concluded that job satisfaction and organizational commitment must be used simultaneously to get better results. In that case, the organization can look for aspects of these variables that have a greater impact. The results from this survey can be a good starting point. The results can be better if the human resources department is involved and is responsible for identifying the strongest aspects that can help improve employee OCB. As part of the management and academic impact of this research is to provide a broader view of the concept of OCB employees and their relationship with certain variables.

The results of this study can contribute to the study of employee behavior towards their organizations. The researcher realizes that this study only analyzes one organization. This study can continue with the focus of the study of OCB employees and other aspects of organizational behavior by using more objects from various companies in the district of Kutai Kartanegara and Indonesia.

Our recommendations are (1) as a business entity engaged in community service, PDAM Tirta Mahakam has to focus not only on gaining profit but also on the welfare of its employees. Increasing OCB will make a strong social system in the company, (2) Employees of PDAM Tirta Mahakam show a high level of job satisfaction. Nonetheless, the company has to maintain that high level of job satisfaction as to ensure business development. Management must be careful in doing promotion, which means that employees must be placed according to their ability to ensure a good working environment, (3) PDAM Tirta Mahakam must maintain the existing organizational commitment to increasing OCB of employees. Clarity of roles of employees and explanation of the goals of the company will help employees adjust themselves to their work better. Improving the ability of employees, such as through training, will be beneficial for the organizational commitment of employees, (4) Intense communication between the management of PDAM Tirta Mahakam and employees is a necessity to create a sense of belonging to the company, (5) Further studies may include other variables that can influence OCB, such as leadership style, years of service, trust in the leadership, and organizational culture, to complement this research, and (6) Three areas of future research appear particularly fruitful. First, better understanding the organizational structures and practices that allow OCBs to emerge, and considering how they could be used to maximise performance, would have interesting implications for employers. Second, exploring what group practices and mechanisms allow diverse intelligence types to maximise their performance would facilitate OCBs and employee satisfaction. Third, learning how to differentiate between those behaviours that are beneficial to all versus those that promote job creep, a poor work/life balance and other negative effects will help maintain a healthy work environment. The tipping point from positive to negative OCB may be linked to the extent of the behaviour, the way it is encouraged by colleagues and employers, or indeed pre- existing personality traits. 


\section{REFERENCES}

Al-Jabari, B., \& Ghazzawi, I. (2019). Organizational Commitment : A Review of the Conceptual and Empirical Literature and a Research Agenda. International Leadership Journal, 11(1), 78-119.

Ariani, D. W. (2014). Relationship Personality, Job Satisfaction, Organizational Commitment and Organizational Citizenship Behavior of Service Industries in Indonesia. Research Journal of Business Management, 8(3), 262-283.

Basim, H., \& Şeşen, H. (2006). Adaptation and Comparison of Organizational Citizenship Behavior Scale (Vol. 61). Ankara University, Faculty of Political Sciences.

Chahal, H., \& Mehta, S. (2010). Antecedents and Consequences of Organisational Citizenship Behaviour (OCB): A Conceptual Framework in Reference to Health Care Sector. Journal of Services Research, 10(2 (October 2010-March 2011)), 25-44.

Dessler, G. (2013). Human Resource Management (13th ed.). New Jersey: Prentice Hall, Inc.

Grego-planer, D. (2019). The Relationship between Organizational Commitment and Organizational Citizenship Behaviors in the Public and Private Sectors. Sustainability, 11(6395), 1-20.

Intaraprasong, B., Dityen, W., \& Krugkrunjit, P. . (2012). Job Satisfaction and Organizational Citizenship Behavior of Personnel at One University Hospital in Thailand. Journal Med Assoc Thai, 95(6), 102-108.

Jackson, S. E., Schuler, R. S., \& Jiang, K. (2014). An Aspirational Framework for Strategic Human Resource Management. The Academy of Management Annals, 8(1), 1-56. https://doi.org/10.1080/19416520.2014.872335

Khan, S. K., \& Rashid, M. Z. H. A. (2015). The Mediating Effect of Organization Commitment in the Organization Culture, Leadership and Organization Justice Relationship with Organization Citizenship Behaviour: A study of Academics in Private Higher Learning Institutions in Malaysia. International Journal of Recent Advances in Organizational Behaviour and Decision Sciences (IJRAOB), 1(2), 335-359.

Koning, L. F., \& Kleef, G. A. Van. (2015). How Leaders' emotional Displays Shape Followers' organizational Citizenship Behavior. The Leadership Quarterly, 26, 489-501.

Mathis, R. ., \& Jackson, J. . (2010). Human Resource Management (13th ed.). Ohio: South Western College Publishing.

Mercurio, Z. A. (2015). Affective Commitment as a Core Essence of Organizational Commitment: An Integrative Literature Review. Human Resource Development Review, 14(4), 389-414. https://doi.org/10.1177/1534484315603612

Organ, D. W., \& Lingl, A. (1995). Personality, Satisfaction, and Organizational Citizenship Behavior. The Journal of Social Psychology, 135(3), 339-350.

Pavalache-ilie, M. (2013). Organizational Citizenship Behaviour, Work Satisfaction and Employees' personality. Procedia - Social and Behavioral Sciences, 127(2014), 489493. https://doi.org/10.1016/j.sbspro.2014.03.296 
Podsakoff, N. ., Podsakoff, P. ., MacKenzie, S. ., Maynes, T. ., \& Spoelma, T. . (2014). Consequences of unit- level organizational citizenship behaviors: A review and recommendations for future research. Journal of Organizational Behavior, 35(S1), S87S119.

Rajeswari, P., \& Adhimoolam, R. (2015). Job Dimension Towards Job Satisfaction and Commitment: A Review Report. International Journal of Advanced Scientiific Research \& Development, 02(02), 50-58.

Ramawickrama, J., Opatha, H., \& Kumari, M. D. P. (2017). Quality of Work Life, Job Satisfaction, and the Facets of the Relationship between the Two Constructs. International Business Research, 10(4), 173-176.

Robbins, Stephen, P., Judge, \& Timothy, A. (2013). Organizational Behavior (15th ed.). New Jersey: Pearson Education Inc.

Shafazawana, M. T., Ying, C. Y., Zuliawati, M. S., \& Sukumaran, K. a/p. (2015). Managing Job Attitudes: The Roles of Job Satisfaction and Organizational Commitment on Organizational Citizenship Behaviors. Procedia Economics and Finance, 35(2016), 604-611. https://doi.org/10.1016/S2212-5671(16)00074-5

Sugiyono. (2015). Metode Penelitian Pendidikan. Bandung: Alfabeta.

Telaumbanua, F. A. N., Sinulingga, S., \& Iskandarini. (2019). Effect of Organizational Commitment, Motivation and Job Satisfaction on Employee Performance at Prof . DR . Muhammad Ildrem Mental Hospital. IOSR Journal of Business and Management, 21(5), 49-53. https://doi.org/10.9790/487X-2105014953

Yilmaz, R., \& Bulut, F. M. (2015). The Effect of Human Resources Management on Organisational Performance. KNUV, 2(44), 5-13.

Zayas-ortiz, M., Rosario, E., Marquez, E., \& Gruñeiro, P. C. (2015). Relationship Between Organizational Commitments and Organizational Citizenship Behaviour in a Sample of Private Banking Employees. International Journal of Sociology and Social Policy, 35(1/2), 91-106. https://doi.org/10.1108/IJSSP-02-2014-0010 